\title{
15
}

\section{Neoliberal rhetoric and guardian state outcomes in Aboriginal land reform}

\author{
Leon Terrill
}

\section{Introduction}

When the Forrest Review was released in August 2014, few people would have been surprised to find that it included several recommendations with respect to land tenure reform in Aboriginal communities (Forrest 2014: 58-60). This was the latest instalment in an ongoing public dialogue about Aboriginal land reform in Australia. It is a discussion that began in earnest a little over a decade ago and has continued (at times quietly, at times prominently) throughout the period since. Since 2006, it has been accompanied by several sets of reforms: township leases, five-year leases, housing precinct leases, 'secure tenure' policies and, most recently, legislation to allow 'ordinary freehold title' in 34 Aboriginal and Torres Strait Islander communities in Queensland.

In this chapter, I argue that while public dialogue about the reforms has been dominated by neoliberal rhetoric the reforms themselves are, for the most part, better characterised in terms of guardianship or paternalism. I will also argue that this has been a form of neoliberal paternalism. This means that references to neoliberalism are not 
entirely misplaced, however it is paternalism that is the more defining element of the reforms. The reason this matters is because neoliberalism suggests the introduction of markets where those markets will have the disciplining effect of encouraging the development of individual motivation and resilience; whereas neoliberal paternalism instead describes how the government itself takes on the task of disciplining individuals, as part of a project of preparing those individuals to become capable market agents. The difference, which is significant, is with respect to the role played by governments.

I finish the chapter by asking two questions: What is the significance of the disjuncture between language and practice? And who should play the role of guardian with respect to land administration in Aboriginal communities?

\section{Debate about Aboriginal land reform in Australia}

A short chapter cannot authoritatively reproduce a decade-long debate. Instead, a representative sample of quotes is provided here that embody the dominant themes of the debate, particularly as they were articulated by those in favour of reform. ${ }^{1}$

The first quote is from a discussion paper by Noel Pearson and Lara Kostakidis-Lianos (2004). The authors argue that a 'key structural problem faced by many Indigenous people, particularly those living in remote communities, is the fact that they live in a welfare economy outside the mainstream Australian (real) economy'. They identify several reasons for this, but emphasise that this 'isolation is cemented $\ldots$ by specifically Indigenous landholding structures' (Pearson \& Kostakidis-Lianos 2004: 1). Without being prescriptive, they argue that changes to land ownership are needed to allow Indigenous people in those communities to participate more fully in the 'real economy'.

1 For brevity I omit reference to statements about secure tenure, which were favoured by the Rudd-Gillard Labor governments but appeared to have been dropped by the Abbott Coalition Government. 
Echoing similar themes, later that year Warren Mundine announced that Indigenous Australians 'need to move away from communal land ownership and non-profit community-based businesses and take up home ownership, economic land development and profit-making businesses' (quoted in Metherell 2004). Mundine's comments were widely reported and provoked a number of responses, including a statement of endorsement by Prime Minister John Howard (Bradfield 2005: 3). The following April, Howard announced that his government planned to introduce reforms to enable individual ownership, for the reason that '[h]aving title to something is the key to your sense of individuality, it's the key to your capacity to achieve, and to care for your family' and that he didn't 'believe that indigenous Australians should be treated differently in this respect' (quoted in Grattan 2005). Here the formative role of property ownership is made explicit. The Prime Minister saw land reform not just as an avenue for economic development, but also as a means of altering the norms and behaviours of people living in Aboriginal communities. As Michelle Grattan (2005) said at the time, the Prime Minister appeared to be 'bent on taking the white picket fence to remote Aboriginal Australia'.

The Australian newspaper editorialised in favour of the reforms on several occasions. They described how there was a 'revolution under way in thinking about black land rights in Australia', which had been given 'tangible shape in the Howard Government's plan ... to allow individuals to privately own what is now communal property' (The Australian 2005). They characterised this as 'the most determined effort yet to create an enterprise culture within Aboriginal communities', again referring to a change of culture.

More recently, current Minister for Indigenous Affairs Senator Nigel Scullion (2014) argued that:

Land tenure reform is not about benefiting government and it is not about giving government control of the land.

It is about giving Aboriginal people the same opportunities and responsibilities as other Australians to own their own homes, and leverage their land assets to generate wealth for the benefit of themselves, their families and their community.

I return to this statement below, to argue that it misrepresents the impact of recent reforms. 


\section{Neoliberal themes}

These and related statements suggest that the role of land reform is to bring Aboriginal communities into the mainstream economy, not just to enable greater wealth creation but so that the introduction of markets might alter community norms by creating the incentives for individual endeavour and fostering an 'enterprise culture'. There are some bold assumptions being made here about the role of existing tenure arrangements in preventing economic development, but that is not the focus of this chapter. Instead, I wish to clarify what these statements suggest about the role of governments.

To borrow from a related context, the theme here is very much along the lines of 'normalise, exit'. These statements suggest that the role of government is to enable markets, or to remove barriers to the entry of markets, and to then get out of the way and allow those markets to do their work, to have their impact both in terms of wealth formation and norm development. Below I contrast this with the reforms themselves.

\section{The reforms}

As it is not possible here to describe all of the recent reforms - which include the five-year leases, 'secure tenure' policies, permit reforms, and changes to leasing in Queensland-I am going to concentrate on the Australian Government's flagship reform, which is township leasing in the Northern Territory.

To understand what township leases do it is necessary to begin with the situation before they were introduced. Previously, most infrastructure in communities on Aboriginal land was allocated under informal arrangements. That is, there were very few leases formalising the relationship between the Aboriginal landowners and the occupiers of each individual lot. For example, while the local council was the sole occupier of buildings such as council offices, workshops and staff accommodation, its rights to do so were informal rather than legal. While this might sound precarious, and it did have flaws, it appears that these informal arrangements were relatively stable and for several decades provided the basis for land use in communities on Aboriginal land. 
What a township lease does is to formalise these tenure arrangements through a two-step process (Terrill 2014). The first step is that the entire community is leased to a statutory body called the Executive Director of Township Leasing (EDTL). This is the township lease and it is in the nature of a head lease. The next step is that the EDTL grants a sublease to each and every occupier, so that their right to occupy is made formal.

What differentiates township leasing from other formalising models is the role of the EDTL. That is, the function of a township lease is not just to formalise tenure through the grant of subleases, but to put the EDTL in charge of the process for doing so, rather than community residents or traditional owners or some other persons. This is of course an ongoing role. Once subleases have been granted, they must then be administered and ultimately renewed.

\section{Wurrumiyanga}

The first township lease was granted over the community of Wurrumiyanga (formerly Nguiu) in 2007. By now almost all lots within the community have been subleased, and I have been studying the way in which subleases have been granted. A key point is that township leasing has not led to the creation of a market in subleases. There are several reasons for this, one of which is the terms of the subleases themselves. While there is some variation, a typical sublease runs for about 20 years, is subject to ongoing rent, contains a long list of restrictions on use, and can only be transferred with the consent of the EDTL (which cannot be unreasonably withheld).

There are a small number of exceptions, the most notable being the grant of 16 home ownership subleases. These truly are in a marketable form (although to date there is no record of any being traded). This is because they run for much longer - up to 99 years - and are not subject to ongoing rent. They represent value, whereas most other subleases, with their ongoing rental obligation, have been described as arguably being 'a business liability rather than an asset' (Beadman 2010: 76).

The 16 home ownership subleases also represent a tiny fraction of all residential housing in the community. The other approximately 281 houses have instead been subleased long-term to Territory 
Housing (Watson 2010: 9). This is because since 2007 the Australian Government has required that all residential housing in Indigenous communities be leased or subleased to the relevant State or Territory housing department. Previously, housing in Indigenous communities was a form of community housing managed by bodies called Indigenous Community Housing Organisations or ICHOs. As a result of these reforms it is now public housing, controlled and managed by the mainstream government housing body. This has been a far more widespread reform than the very limited introduction of home ownership.

Beyond the limited introduction of home ownership, which after all does not require a community-wide leasing scheme, there is no market in subleases in any of the existing township lease communities. They are not being bought and sold for value or at a market price because they are more like a liability than an asset. And contrary to what the Minister has suggested (Scullion 2014), those subleases are not a form of property that can be leveraged to create wealth. Instead, the main economic impact of township leasing has been a significant increase in the amount of rent being paid by occupiers such as enterprises and service providers. Most of this rent will ultimately be passed on to the traditional owners for that land.

If I were to make one comment on this as an economic model it would be to say that Hernando de Soto (2001) would not be happy. This is not capital creating in the sense he envisages. Nor is it coherently neoliberal in any meaningful sense. There is no market and the most widespread 'price', which is the amount of rent paid on subleases, is unilaterally set by the EDTL.

\section{Neoliberal or paternal?}

The reason I argue that it is misleading to simply describe these reforms as neoliberal is because that term suggests the introduction of markets, with markets then playing a formative role in the development of individuals and of society. This is made explicit in some of the quotes described above, however that is not what has happened under recent reforms. 
They are better characterised as what Soss et al. (2011) refer to as 'neoliberal paternalism'. They describe how:

... neoliberalism and paternalism converge on a distinctive agenda for poverty governance. Together, they define a strong state-led effort to bring discipline to the lives of the poor so that they can become competent actors who recognize and act on their own interests as freely choosing agents of the market (Soss et al. 2011: 27).

Australians are already familiar with this approach being used and advocated in the context of welfare reform. For example, the Forrest review recommends the introduction of a cashless welfare card to protect people who are at 'risk of making poor, short-term purchase decisions' and to 'assist individual responsibility by eliminating spending on alcohol, gambling, and instruments that can be converted to cash like gift cards' (Forrest 2014: 102, 104). State-led discipline is required in the short-term so that individuals can make better decisions in the long-term.

I suggest that neoliberal paternalism also describes many, though not all, of the recent land reforms. ${ }^{2}$ It is not that the government is enabling markets and allowing those markets to have their impact on individuals. It is that governments have taken on the role themselves of disciplining individuals. With respect to housing, I have found a rare quote in which this role is made explicit with respect to the broader housing reforms described above:

Tenants are required to sign up to, and adhere to, normal tenancy agreements - an important lever to rebuild positive community values and behaviour. These reforms will also see tenants required to pay regular and standardised rent and meet care of property requirements. This is part of developing the personal responsibility and individual financial resilience and discipline that is also required to purchase and pay off a home (Australian Government 2010: 14).

2 Most notably, recent Queensland legislation to allow partitioning of Indigenous land might more aptly be described as neoliberal, see the Aboriginal and Torres Strait Islander Land (Providing Freehold) and Other Legislation Amendment Act 2014 (Qld). That legislation raises a number of issues that are not addressed here. 
In other words, the state has inserted itself into housing tenure arrangements so as to provide a higher level of discipline, which will in turn enable individuals to better meet the responsibilities of being a 'competent actor', more capable of purchasing their own home.

This raises a number of important questions, including the question of how well governments are equipped to take on this disciplining role, particularly in the context of Aboriginal communities. Those questions are elided when debate is instead conducted as if governments were introducing mainstream forms of property and then getting out of the way.

\section{What is the significance of this disjuncture?}

Such a significant disjuncture between language and practice cannot be accidental. One reason for it appears to be reluctance on the part of governments to publicly admit to their new, more intrusive role. This is apparent in the recent quote from the Minister for Indigenous Affairs (Scullion 2014), in which he states that land tenure reform 'is not about benefiting government and it is not about giving government control of the land'. I agree that land tenure reform is not about benefiting government, however the statement that it is not about giving government control over land is patently incorrect.

So why is the Minister reticent to admit this? I am yet to find a satisfactory answer to this. It is partly explained by the fact that this new, expanded role for government is at odds with some views of what liberalism and neoliberalism should entail. Tellingly, the Centre for Independent Studies, a neoliberal think tank, has criticised township leases for the fact that they are held by the government and not by the community. They argue that 'governments should step back and enable communities to decide how to lease their land' (Hudson 2009: vii).

It is also notable that when the Forrest review refers to paternalism it ascribes a negative value to the term. It argues that '[i]n a nutshell, it's time to end the paternalism, to expect able first Australians to stand on their own feet and become independent' (Forrest 2014: 3). Australian governments have often expressed similar sentiments. Yet there is a tension between this and governments taking on a new 
and greater role in the management of Aboriginal communities. Resolving this tension requires an evolved set of theory and messaging that the government may not yet have developed.

It could be argued that it is simply more politically expedient for the government to promote land reform using the language of individual autonomy. However it is not just the government who employs this language, its use has been widespread. It does not appear that this has been manufactured to conceal an alternative agenda. It is more likely that the confusion is genuine, and that it reflects something significant.

\section{Who should play the guardianship role?}

Criticism of the Australian Government's new and more paternalistic approach to land tenure reform takes on a different hue when it is accepted that there might be a genuine need for someone to play a guardianship role with respect to some aspects of land administration in Aboriginal communities. I would argue that one of the reasons the Australian Government has opted for a more controlled approach to subleasing on township leases is because it was aware of the dangers inherent in removing all regulation. Due to the particular social and economic circumstances of remote communities, a community-wide, free market in subleases could be harmful. There is arguably value in retaining some centralised control over allocation.

If it were not the government, who should have this control? Who should manage the grant of leases or subleases to business and service providers? Who should set the amount of rent? If there is a closed market, such as for home ownership, who should decide whether someone is in or out? Who should manage the allocation of social housing? Some of these questions bring into play the relationship between traditional owners and (other) Aboriginal residents. They also raise issues around governance and the need to prevent situations of exploitation and nepotism.

In light of this, it appears that governments currently have an almost reflexive tendency to take the role of decision making upon themselves. There are real issues with this. But even in someone else's hands, I would argue that certain of these decisions are likely 
to entail a certain amount of guardianship. As Sanders (2009) has made clear, guardianship is not simply or always a retrograde concept. It is 'a persistent idea in Australian Indigenous policy' (Sanders 2009: 11, original emphasis), albeit one with a very troubling history. Nevertheless, its ongoing role cannot be ignored or dismissed out of hand, including with respect to land reform.

\section{References}

The Australian (2005). Editorial: Black revolution: economic engagement is the path to prosperity. The Australian 6 October:18.

Australian Government (2010). Indigenous home ownership issues paper, Department of Families, Housing, Community Services and Indigenous Affairs, Canberra.

Beadman B (2010). Northern Territory Coordinator General for Remote Services: Report \#2 December 2009 to May 2010, Northern Territory Government, Darwin.

Bradfield S (2005). White picket fence or Trojan horse? The debate over communal ownership of Indigenous land and individual wealth creation, Land, Rights, Laws: Issues of Native Title 3(3), Native Title Research Unit, Australian Institute of Aboriginal and Torres Strait Islander Studies, Canberra.

de Soto H (2001). The mystery of capital: why capitalism triumphs in the west and fails everywhere else, Black Swan, London.

Forrest A (2014). The Forrest review: creating parity, Commonwealth of Australia, Canberra.

Grattan M (2005). Howard tilts at title fight. The Sunday Age (Melbourne) 10 April:17.

Hudson S (2009). From rhetoric to reality: can 99-year leases lead to homeownership for Indigenous communities? Policy Monograph 92, Centre for Independent Studies, St Leonards NSW.

Metherell M (2004). Land system holds us back, says Mundine. The Sydney Morning Herald (Sydney) 7 December:6. 
Pearson N \& Kostakidis-Lianos L (2004). Building Indigenous capital: removing obstacles to participation in the real economy, Cape York Institute, Cairns.

Sanders W (2009). Ideology, evidence and competing principles in Australian Indigenous affairs: from Brough to Rudd via Pearson and the NTER, Discussion Paper 289, Centre for Aboriginal Economic Policy Research, The Australian National University, Canberra.

Scullion N (2014). Land reform for the future. Koori Mail 26 March.

Soss J, Fording R \& Schram S (2011). Disciplining the poor: neoliberal paternalism and the persistent power of race, University of Chicago Press, Chicago.

Terrill L (2014). What is Township Leasing? Indigenous Law Centre Research Brief, July, Indigenous Law Centre, UNSW, Sydney.

Watson P (2010). Executive Director of Township Leasing Annual Report 2009-2010, Australian Government, Canberra. 
This text is taken from Engaging Indigenous Economy: Debating diverse approaches, edited by Will Sanders, published 2016 by ANU Press, The Australian National University, Canberra, Australia. 